\title{
The relationship of hope to self-compassion, relational social skill, communication apprehension, and life satisfaction
}

\author{
Laura R. Umphrey · John C. Sherblom
}

\begin{abstract}
Hope is a habitual way of thinking about goals, the potential pathways of achieving them and the motivated agency for their accomplishment. Past research shows the beneficial behavioral outcomes of having hope, but little research investigates the relationship of hope to indicators of psychological, relational, communicative, or subjective wellbeing. The present study takes an interdisciplinary approach to test a model of the relationship between hope and wellbeing, as expressed through self-compassion, relational social skill, communication apprehension, and life satisfaction. Results show a pattern of relationships that suggest intervention programs designed to change thinking habits can encourage not only more hopeful thought but also enhanced self-compassion, greater skill in personal relationships, less communication apprehension, and heightened life satisfaction.
\end{abstract}

Keywords: hope, communication apprehension, self-compassion, social skills, life satisfaction, wellbeing

\section{Introduction}

Hope has been treated as a vague, ambiguous concept. Snyder (2000) notes that multiple metaphorical descriptions of hope abound, as in the opinion of Sophocles that it is a human foible; of Plato that it is a foolish counselor; of Euripides that it is a curse; of Francis Bacon that it is a bad supper; of Benjamin Franklin that it is an illusion upon which one could die fasting; and in common parlance that it is a false promise. Recent psychological conceptions portray hope as a character strength, cognitive-motivational influence, expectation, future-oriented positive emotion, relational process, and trait (Hellman, Pittman, \& Munoz, 2013; Hoy, Suldo, \& Mendez, 2013; Moraitou \& Efklides, 2012; Valle, Huebner, \& Suldo, 2006; Yohani, 2008).

Countering this conceptual ambiguity, Snyder $(1994,2000,2002)$ provides a well-considered and widely accepted definition of hope as a phenomenon that is integral to wellbeing. Snyder's definition identifies three necessary components of hope: a goal and two reciprocally influential processes called pathways thinking and agency thinking (Snyder, 2000, 2005; Snyder et al., 1991). These two thought processes work together to accomplish the goal. Through his definition and research Snyder links hope to psychological wellbeing (Snyder, 1994, 2000, 2002).

\section{Snyder's theory of hope}

Historically, hope has been articulated as a vague, passive concept. For example, the statements "Let's hope for the best" and "I hope it rains" assume that the desired goal can be attained without 
any active engagement. This passive conception contrasts with Snyder's active definition of hope in which goals must be actively pursued (Stajkovic, 2006). Snyder's active approach, articulated in statements such as "I hope to finish the race" and "I hope to get an A on my paper," includes a path toward a goal that is pursued with agency (Snyder, 2000, 2002). These path and agency components of hope make Snyder's definition distinct from mere wishing, desiring, or positive thinking.

Hope is an "enduring pattern of thinking about oneself in relation to life goals" (Snyder, 1994, p. 68). It is embodied in the "perceived capabilities to produce routes to desired goals, along with the perceived motivation to use those routes" (Snyder, 2000, p. 8). Pathways thinking consists of the strategies needed to achieve a goal and agency thinking considers self-efficacy and personal motivation necessary components of hope (Kemer \& Atik, 2012). These habits of pathways and agency thinking develop over time as learned dispositions in a person's way of thinking and become mutually influential cognitive processes (Marques, Lopez, \& Pais-Ribeiro, 2011).

\subsection{Goals}

Goals vary in specificity, temporality, importance, likelihood, challenge, consequence, and verbal articulation. Some goals are specific; others are more general in nature. They may be short term, such as accomplishing something today, or long term, such as generating a retirement fund over time. Some goals are more important than others and some have a higher or lower likelihood of achievement (Snyder et al., 2000). Some represent a positive new challenge, continued progress toward an outcome, or sustained achievement. Others seek to avoid a negative consequence, such as divorce, unemployment, or poor health. Some goals are articulated verbally. Others are represented as visual perceptions. Within all of this variability "human actions are goal directed," and these goals are "target[s] of action sequences" that involve pathways and agency thinking (Snyder, 2002, p. 250).

\subsection{Pathways and agency thinking}

Hope represents not just a person's ability to produce a goal, but the creativity to develop strategies and the sustained motivation to achieve that goal (Alidina \& Tettero, 2010). Pathways thinking identifies the strategies that lead to the accomplishment of a goal. People who have hope are able to generate multiple, alternative pathways to achieve their goals. They are, therefore, more likely to attain them even when obstacles block one or more of those pathways (Grewal \& Porter, 2007). Agency thinking represents a pro-active confidence and motivation. It provides "the belief that one can begin and sustain movement along the envisioned pathways toward a given goal" (Snyder et al., 2000, p. 749). Agency reveals the self-efficacy and stamina needed to pursue those multiple alternative pathways, overcome the numerous potential obstacles, and ultimately obtain the goal (Snyder, 2000).

Multiple pathways and adequate agency to change plans as needed and to sustain one's momentum when obstacles are encountered epitomizes the true nature of hope as an ongoing life process (Lopez, Snyder, \& Teramoto-Pedrotti, 2003; Marques, Lopez, \& Pais-Ribeiro, 2011). Beginning in infancy, children observe events, absorb information, and learn to hope. They see patterns of behavior, make predictions about the world around them, learn to anticipate events, and make purposeful plans (Snyder, 1994). This planning involves goal setting.

A child develops a sense of agency for instigating events and pathways to overcome barriers at a young age (Snyder, 1994). A young child placed in a room alone with a toy beyond reach may cry. When a caregiver is present in the room the child can motion to the caregiver for assistance. The caregiver becomes a facilitator who can help the child achieve the goal of 
obtaining the toy. By either assisting or ignoring the child the caregiver fosters or diminishes the child's hopeful thinking (Snyder, 1994). Patterns of pathways and agency thinking develop through these early mundane childhood events. These patterns of thought for articulating goals, identifying pathways for achieving them and experiencing agency continue to develop throughout life.

\subsection{The benefits of hopeful thinking}

People who engage in patterns of hopeful thinking as adolescents and adults are more adaptive in their problem-solving, better able to engage in coping strategies, and less prone to depression (Chang \& Banks, 2007). Hope adds a resiliency for dealing with negative life events, reduces the likelihood of suicide, and increases the potential for success in psychotherapy (Davidson, Wingate, Rasmussen, \& Slish, 2009; Grewal \& Porter, 2007). Higher initial levels of hope in adolescence predict greater life satisfaction a year later, even when controlling for initial levels of life satisfaction (Valle, Huebner, \& Suldo, 2006).

During times of palliative care and terminal illness hope enables people to adapt to the situation, envision moments of happiness, and remain connected with family and friends (Alidina \& Tettero, 2010). Through narratives of hope, acquired brain injury survivors help motivate new patients to redefine themselves, their situations, and their goals for the future. Hopeful narratives inspire and empower new patients and their families, help build positive attitudes toward recovery from acquired brain injury, facilitate success in rehabilitation, and improve their general, overall quality of life (Fraas \& Calvert, 2009). In support groups hope produces the expression of more positive feelings, thoughts, and affection; the use of inclusive words such as "we" and "our;" more communally focused group interaction; and positive change over time (Peterson, 2009).

The research literature shows the personal and behavioral outcomes of hope. Hopeful thinking is reported to produce greater academic achievement, more athletic success, and better job performance (Hoy, Suldo, Mendez, 2013; Kemer \& Atik, 2012; Marques, Lopez, \& Mitchell, 2013; Peterson \& Byron, 2008; Savage \& Smith, 2007). Hopeful thinkers report feeling more selfworth, creativity, mental and physical health, positive emotions, and confident outlook on life (Chang, 1998; Onwuegbuzie \& Daley, 1999). Surprisingly little research, however, investigates the relationship of hope to psychological, relational, communicative, or subjective wellbeing. The present study takes an interdisciplinary approach to explore that relationship of pathways and agency thinking to wellbeing as expressed in self-compassion, relational social skill, communication apprehension, and life satisfaction.

\section{Self-compassion}

Self-compassion occurs as an internal dialogue. It articulates an attitude toward one's self that is associated with happiness, optimism, positive feelings, curiosity, exploration, agreeableness, extroversion, and conscientiousness (Manusov, 2011). Self-compassion means "treating oneself with kindness, care and concern in the face of negative life events" (Terry \& Leary, 2011, p. 352).

People often engage in negative self-talk that involves critical self-judgments, self-blame, unfavorable comparisons of oneself to others, and unrealistic demands on oneself (Rosenberg, 2003). Self-compassionate people see difficult life experiences as part of the human condition and, through inner dialogue, encourage themselves to reflect on their cognitions and emotions, emphasizing the positive rather than the negative (Terry \& Leary, 2011). Self-compassion includes three components: (a) self-kindness, (b) feeling connected in our common humanity, and (c) being mindful (Neff \& Beretvas, 2013). Self-kindness means confronting and accepting 
our personal inadequacies without engaging in relentless self-criticism or being overly harsh in judgments of ourselves (Neff, 2011). Feeling connected means seeing our imperfections as part of the human condition. People make mistakes and through our imperfections we are connected with others in a common humanity (Neff, 2003b). Being mindful involves taking a broader view of life and reflecting on the present moment with awareness and perspective. This means acknowledging our shortcomings rather than suppressing, obsessing, exaggerating, fixating, ruminating over, or becoming identified with one's situation (Neff, 2011). Self-kindness rather than self-judgment, common humanity rather than self-deprecation, and mindfulness rather than identification, form the dimensions of this self-compassion (Neff, 2003a).

Snyder's theory of hope presents pathways and agency as positive ways of thinking about one's self. Although little research investigates the direct connection of hope to self-compassion, people who are more hopeful about their goals appear likely to be more positive in their inner self-talk and less critical of themselves when faced with a challenge, obstacle, or initial failure (Neff, Rude, \& Kirkpatrick, 2007). Hope, as expressed in pathways and agency thinking, should stimulate more compassionate self-talk.

\section{Relational social skill}

Relational social skill is the ability to effectively communicate with others (Segrin, Hanzal, Donnerstein, Taylor, \& Domschke, 2007). It includes interpersonal competence (Burke, Woszidlo, \& Segrin, 2012), communication competence (Spitzberg \& Cupach, 1984), social competence (Arroyo \& Segrin, 2013), social skill (Riggio \& Canary, 2003), and social ability (Platsidou, 2013). These skills recognize the ability to understand a communication context, participate in it appropriately, and communicate effectively in relationships with others (Spitzberg \& Cupach, 1984).

Relational social skill and hope are learned together in early childhood. Parents and other caretakers who are affectionate, receptive, and democratic with their children foster the early development of both hope and relational social skill (Gülay, 2011). Hope and social skills continue to develop and become habitual practices in the everyday relational communication experiences of adulthood. Later experiences modify, contradict, or build upon the early relational patterns of childhood and an individual's ability to conceive of multiple pathways and personal agency, and the relationship of self to others develops throughout life (Snyder \& Lopez, 2007).

Hope has been shown to be related to relational closeness and to perceived social acceptance. A study of college students found a significant association between hope and acceptance in close, personal relationships (Onwuegbuzie \& Daley, 1999). Self-compassion has been shown to be related to close, personal relationships as well (Neff \& Beretvas, 2013). Self-compassionate individuals demonstrate greater social skill in managing their relational behaviors. They tend to be more compassionate toward others, provide more social support, encourage interpersonal trust, resolve conflicts with compromise, and balance the needs of self and others more effectively (Neff \& Beretvas, 2013). This compassion expressed toward others helps build more positive interpersonal relationships (Mongrain, Chin, \& Shapira, 2011).

\section{Communication apprehension}

Communication apprehension is one of the most fully explored concepts in the communication research literature (Wrench, Brogan, McCroskey, \& Jowi, 2008). It expresses a social uneasiness, shyness, reticence, phobia, and withdrawal from conversation that is associated with a perceived lack of communication competence (Honeycutt, Choi, \& DeBerry, 2009; Jung, 2011; McCroskey, 1983; Pearson, Child, DeGreeff, Semlak, \& Burnett, 2011). It represents a relatively enduring sense 
of discomfort, anxiety, and fear that some individuals experience when anticipating and while communicating that "can hinder one's ability to communicate interpersonally" (Rubin \& Rubin, 1989, p. 13). This anxiety and fear reduces self-disclosure, affects relational maintenance behaviors, and diminishes the potential for relationship growth (Bevan, 2009; Loveless, Powers, \& Jordan, 2008). People who are apprehensive show an unwillingness toward, avoidance of, withdrawal from, and difficulty in communicating (Jung, 2011). They talk less, maintain more social distance, choose to be physically remote, develop fewer personal relationships, express less satisfaction in their relationships, and interact less with strangers. However, they do not differ in an expressed need and desire for close relationships (McCroskey \& Sheahan, 1978).

Past communication experiences, mistakes, positive and negative feedback from others, encouragement, reinforcement, and social modeling have been shown to be antecedents of communication apprehension (Ayres, 1988). Interpersonal uncertainty, anxiety over one's social skill, and perceived ability to clarify one's thoughts and feelings are also related (Honeycutt, Choi, \& DeBerry, 2009). Yet, little research has examined the relationship of communication apprehension to either hope or self-compassion. However, communication apprehension is related to self-construal (Merz, 2009). Self-construal refers to the degree to which a person defines oneself as independent or interdependent with others. Individuals who have an independent self-construal, who recognize more personal agency in achieving goals, and who view internal thoughts, feelings, and abilities as the primary sources of success are known to express less communication apprehension. A person with an interdependent self-construal, who sees external chance, powerful others, and context as more influential in their pursuits expresses greater communication apprehension (Merz, 2009).

This research indicates the potential relationships of hope, self-compassion, and relational social skill to communication apprehension. To date, however, researchers have not examined these relationships. The present study investigates them and predicts that communication apprehension is related to hope, self-compassion, and relational social skill. People who engage in more pathways and agency thinking, who express more self-compassion, and who exhibit more relational social skill are less likely to experience communication apprehension.

\section{Subjective wellbeing and life satisfaction}

Subjective wellbeing is a multi-dimensional construct. It has physical, psychological, spiritual, and social dimensions that are experienced within the domains of family, community, and societal life (LaPlaca, McNaught, \& Knight, 2013). Individuals actively cultivate a sense of subjective wellbeing within these social contexts (Uchida \& Ogihara, 2012). These interrelated dimensions of wellbeing include a cognitive sense of life satisfaction and the emotional experience of happiness expressed in the presence of positive and a lack of negative feelings toward oneself (Angner, 2011; Dodge, Daly, Huyton, \& Sanders, 2012).

Life satisfaction builds on a set of cognitive judgments that a person makes about his or her life. This self-assessment evaluates the quality of one's life using subjective standards (Diener, Emmons, Larsen, \& Griffin, 1985). It applies a set of personal judgments about how an individual's life matches up to a pre-conceived ideal life-plan. These judgments include evaluations of the past, present, and anticipated future and compares a person's life to the lives of salient others (Ivtzan, Gardner, \& Smailova, 2011; Suikkanen, 2011).

Happiness, on the other hand, is a subjective experience. It identifies the ratio of positive to negative feelings one has toward oneself (Shmotkin, 2005). This experience of happiness is related to hope, self-respect, self-esteem, optimism, gratitude, humility, personal forgiveness, acceptance of tragedy, working through grief, and the relinquishing of regrets (Martin, 2008). 
Shmotkin (2005) describes the association between life satisfaction and happiness as an overall conception of subjective wellbeing that people make about their lives. This conception of subjective wellbeing includes life satisfaction and happiness and is represented in a lack of personal anxiety and apprehension (La Placa, McNaught, \& Knight, 2013). Researchers often use the Satisfaction with Life scale to measure happiness and have shown correlations in participant responses to this scale and to the Subjective Happiness scale (Demir, 2008; Demir, Ozdemir, \& Weitekamp, 2007).

Life satisfaction is a key indicator of subjective wellbeing in ways that are related to the present study of hope, compassion, and relational social skill (Bailey \& Snyder, 2007; Bronk, Hill, Lapsley, Talib, \& Finch, 2009; Helliwell \& Wang, 2011; O'Sullivan, 2011). Hope predicts high levels of life satisfaction (Hoy, Suldo, Mendez, 2013; Kemer \& Atik, 2012; Moraitou \& Efklides, 2012). Agency and pathways thinking predict life satisfaction better than reduced stress or high self-efficacy do (Bailey, Eng, Frisch, \& Snyder, 2007; O'Sullivan, 2011). Self-compassion also affects life satisfaction, happiness, and subjective wellbeing. People with higher levels of selfcompassion report lower levels of anxiety, depression, and neurotic perfectionism (Neff \& Beretvas, 2013). Engaging in compassionate action toward oneself and toward others increases happiness (Mongrain, Chin, \& Shapira, 2011). Greater relational social skill, as expressed in the willingness to confide in one's partner and the ability to handle relational conflict, increases life satisfaction as well (Gere \& Schimmack, 2013; Platsidou, 2013).

\section{The present study}

Past research studies indicate that hope is related to self-compassion, with more positive and less critical self-talk anticipated when an individual is faced with a challenge or initial failure in achieving a goal (Neff, Rude, \& Kirkpatrick, 2007). Both hope and self-compassion are associated with relational social skill and interpersonal closeness (Mongrain, Chin, \& Shapira, 2011; Neff \& Beretvas, 2013; Onwuegbuzie \& Daley, 1999). Communication apprehension may be related to hope, self-compassion, and relational social skill. Past experiences, encouragement, mistakes, reinforcement, negative feedback, social modeling, interpersonal anxiety, and self-construal all form antecedents to communication apprehension (Ayres, 1988; Honeycutt, Choi, \& DeBerry, 2009; Merz, 2009). Hope, self-compassion, and relational social skill each individually predict life satisfaction (Gere \& Schimmack, 2013; Hoy, Suldo, Mendez, 2013; Kemer \& Atik, 2012; Mongrain, Chin, \& Shapira, 2011; Moraitou \& Efklides, 2012; Neff \& Beretvas, 2013; Platsidou, 2013). These individual relationships are noted in the literature. However, no research has investigated the multiple, simultaneous relationships among hope, self-compassion, relational social skill, communication apprehension, and life satisfaction in the same study.

The present study brings an interdisciplinary approach to examine a model of these multiple relationships. That model simultaneously tests the relationships of pathways and agency thinking to self-compassion, relational social skill, communication apprehension, and life satisfaction, looking for patterns of interaction across psychological, relational, communication and subjective aspects of wellbeing. We anticipate that hope is related to communication apprehension and life satisfaction, but not in isolation. Based upon the research literature the model predicts a pattern of mutually interacting and reinforcing relationships that include pathways and agency thinking in combination with self-compassion and relational social skill in people's experiences of communication apprehension and life satisfaction.

The model predicts that self-compassion is influenced by pathways and agency thinking. Relational social skill is affected by all three, with its relationship to pathways and agency thinking being partially mediated by self-compassion. Likewise, both communication 
apprehension and life satisfaction are related directly and through mediated connections to pathways and agency thinking, self-compassion, and relational social skill.

Recent research shows that training in hope can enhance the pathways and agency thinking of certain populations (Feldman \& Dreher, 2012; Marques, Lopez, and Pais-Ribeiro, 2011; Valle, Huebner, \& Suldo, 2006; Yohani, 2008). Demonstrating the relationships tested in the present model can promote positive outcomes not just for the habits of pathways and agency thinking but for self-compassion, relational social skill, communication apprehension, and life satisfaction as well. Showing the connections of pathways and agency thinking to self-compassion, relational social skill, communication apprehension, and life satisfaction can suggest training programs to facilitate each.

\section{Hypotheses}

Hypothesis 1: Hope, as expressed through pathways and agency thinking, predicts more selfcompassion;

Hypothesis 2: Hope, as expressed through pathways and agency thinking, predicts more relational social skill;

Hypothesis 3: Hope, as expressed through pathways and agency thinking, predicts reduced communication apprehension;

Hypothesis 4: Hope, as expressed through pathways and agency thinking, predicts greater life satisfaction;

Hypothesis 5: Self-compassion mediates the relationship of pathways and agency thinking to relational social skill, communication apprehension, and life satisfaction;

Hypothesis 6: Relational social skill mediates the relationship of pathways and agency thinking to communication apprehension and life satisfaction.

\section{Method}

A sample of 308 participants responded to questions measuring perceptions of hope, selfcompassion, social skill, communication apprehension, and life satisfaction. The survey took 15 to 20 minutes to complete. Demographic information was collected at the end of the survey.

\subsection{Procedure}

Approval for the research study was granted by the institutional review board at the first author's institution. Following approval the first author contacted instructors of online courses at a medium-sized university in the southwestern United States and asked permission to recruit students for participation in the study. When permission was granted volunteer participants were recruited through an email that informed them of the nature of the study and their rights as human subjects. The online survey process maintained the anonymity of participants and extra credit was offered for participation. When students completed the survey a "secret phrase" was provided to them that they could relay to their instructor to receive the extra credit. Table 1 below shows the sample demographic information.

To be included in the study participants had to first identify a specific personal goal. Then they were asked to complete the survey measures. The self-report survey measures of pathways and agency thinking, self-compassion, relational social skill, communication apprehension, and life satisfaction were responded to on five-point Likert-type scales, with response choices ranging from 1-strongly disagree to 5-strongly agree. Several scales for each measure were reverse coded 
to reduce the likelihood of response bias. Self-report measures have been shown to perform well, and sometimes better than other measures, in the assessment of happiness, satisfaction, and subjective wellbeing (Angner, 2011; Platsidou, 2013).

Table 1. Sample demographic frequencies

\begin{tabular}{llrl}
\hline Gender & Female & 215 & $(70 \%)$ \\
& Male & 93 & $(30 \%)$ \\
\hline Race-ethnicity & Caucasian & 209 & $(67 \%)$ \\
& African American & 13 & $(4 \%)$ \\
& Asian/Pacific Islanders & 5 & $(2 \%)$ \\
& Hispanic & 62 & $(20 \%)$ \\
& Native American & 8 & $(3 \%)$ \\
& Other & 11 & $(4 \%)$ \\
\hline Age & $18-21$ & 62 & $(20 \%)$ \\
& $22-25$ & 89 & $(29 \%)$ \\
& $26-29$ & 44 & $(14 \%)$ \\
& $31-39$ & 60 & $(19 \%)$ \\
& $40-49$ & 36 & $(12 \%)$ \\
& 50 or older & 17 & $(6 \%)$ \\
\hline Marital status & Single, never married & 172 & $(56 \%)$ \\
& Married & 111 & $(36 \%)$ \\
& Separated & 3 & $(1 \%)$ \\
& Divorced & 22 & $(7 \%)$ \\
\hline
\end{tabular}

Note: $\mathrm{N}=308$

\subsection{Measures}

Hope. The present study used Snyder's (1994) measure of hope to examine pathways and agency thinking. Four items on this scale measure pathways thinking through responses to statements such as, "I can think of many ways to get out of a jam." Four items measure agency thinking through responses to items such as, "Even when others get discouraged, I know I can find a way to solve the problem." This scale, and modifications of it for use with particular samples such as children, adults, and other sub-groups of the population, has been reported in the literature as a valid and reliable measure of hope (Chang \& Banks, 2007; Hoy, Suldo, \& Mendez, 2013; Kemer \& Atik, 2012; Marques, Lopez, \& Mitchell, 2013; Moraitou \& Efklides, 2012). Responses in the present study achieved a Cronbach's alpha coefficient of $\alpha=.79$, showing good internal reliability for the measure.

Self-Compassion. Neff's (2003b) 26-item Self-Compassion Scale is commonly used to measure self-compassion (Akin \& Eroglu, 2013; Baker \& McNulty, 2011; Neff \& Beretvas, 2013). In 2011 Raes and colleagues developed and tested a 12-item short version of this scale (Raes, Pommier, Neff, \& Van Gucht, 2011). Raes et al. (2011) demonstrate that the 12-item short form of the SelfCompassion Scale is a valid and reliable index that taps the same self-compassion construct as the 26-item scale. Their results show that responses to the 12-item scale reproduce the underlying self-compassion factor structure and the higher-order single factor identifying self-compassion that is indexed by the 26-item scale. To reduce the potential of respondent fatigue the present study used the 12-item measure of self-compassion (Raes et al., 2011). The Cronbach's alpha coefficient for this scale of $\alpha=.75$ shows good reliability in the present study. 
Relational Social Skill. Riggio (1986) conceptualizes social skill as an adeptness at sending, receiving, and managing communication with other people. This adeptness includes skill at regulating both the social-verbal and emotional-nonverbal aspects of communication. Riggio originally measured these social-communication skills using a 90-item, self-report social skills inventory. More recently some researchers have used a shorter 30-item form of this inventory to assess the emotional expressivity, emotional sensitivity, emotional control, social expressivity, social sensitivity, and social control dimensions of social skill (Riggio \& Canary, 2003; Segrin et al., 2007). Both studies show the 30 -item form of the measure to have good reliability and validity in indexing the six emotional and social dimensions comprising the relational social skill construct. To reduce participant response burden the shorter 30-item version of the social skills inventory was used in the present study. The Cronbach's alpha coefficient of $\alpha=.81$ achieved in the present study shows a good reliability for this scale.

Communication Apprehension. The personal report of communication apprehension (PRCA) was used to measure communication apprehension (McCroskey \& Beatty, 1984). This scale includes items such as, "I have no fear of speaking up in conversations" and "I'm afraid to speak up in conversations." This scale has been shown to be a valid and reliable measure of communication apprehension (McCroskey \& Beatty, 1984; McCroskey, Beatty, Kearney, \& Plax, 1985). It is the predominant measure of communication apprehension found in the literature and continues to be used in numerous studies (Baiocchi-Wagner, 2011; Honeycutt, Choi, \& DeBerry, 2009; Jung, 2011; Merz, 2009; Wrench, Brogan, McCroskey, \& Jowi, 2008). The Cronbach's alpha coefficient, $\alpha=.96$, shows an excellent internal reliability for this scale in the present study.

Life Satisfaction. The satisfaction with life scale was used to assess life satisfaction in the present study (Diener, Emmons, Larsen, \& Griffin, 1985). This scale measures a global cognitive evaluation of one's life (Demir, Ozdemir, \& Weitekamp, 2007). It has been used by a number of researchers to index life satisfaction and has shown good construct validity, reliability, and independence from momentary participant mood swings (Demir, 2008; Reich, Kessel, \& Bernieri, 2013). The scale consists of 5 items, including, "In most ways my life is close to my ideal." The Cronbach's alpha coefficient, $\alpha=.88$, shows good internal reliability. The means and standard deviations for each scale are reported in Table 2 below.

Table 2. Means and Standard Deviations

\begin{tabular}{lll}
\hline Scale & Mean & SD \\
\hline Hope: Pathways Thinking & 4.13 & .52 \\
Hope: Agency Thinking & 4.10 & .52 \\
Self-Compassion & 4.75 & .53 \\
Relational Social Skill & 3.41 & .39 \\
Communication Apprehension & 3.46 & .71 \\
Life Satisfaction & 3.49 & .84 \\
\hline
\end{tabular}

Note: $\mathrm{N}=308$

\section{Analysis}

Correlation and path analysis were performed to show the relationships among participant scores on these scales. The correlations were calculated using the IBM SPSS 21 statistics software package. The structural equation path analysis model was produced with IBM SPSS AMOS 21.

Path analysis provides a tool to simultaneously test the multiple relationships of pathways and agency thinking to self-compassion (H1), relational social skill (H2), communication 
apprehension (H3), and life satisfaction ( $\mathrm{H} 4)$, the relationships of self-compassion to relational social skill (H5), and of self-compassion (H5) and social skill (H6) to communication apprehension and life satisfaction. An initial full model of these relationships showed that the links between pathways thinking and life satisfaction $(\beta=.04)$ and between agency thinking and communication apprehension $(\beta<.01)$ were relatively weak. Following standard structural equation modeling procedures the agency thinking to communication apprehension link, which was the weakest, was removed first and then the pathways thinking to life satisfaction link was dropped from the model (Tabachnick \& Fidell, 2013). The removal of these two links improved the overall model fit to the data. The final model is presented without these two weak links.

The goodness of model fit to the data was tested using the $\chi^{2}$ test, $\chi^{2}$ to degrees of freedom ratio, comparative fit index (CFI), normed fit index (NFI), relative fit index (RFI), and root mean square error of approximation (RMSEA). Tabachnick and Fidell (2013) provide rationales, descriptions, and criteria for these indices. The present goodness of fit test results of: $\chi^{2}=5.19, d f$ $=3, p=.158, \chi^{2} / d f$ ratio $=1.73, \mathrm{CFI}=.99, \mathrm{NFI}=.99, \mathrm{RFI}=.95$, and RMSEA $=.05$ demonstrate a good model fit.

\section{Results}

\subsection{Correlations}

Table 3 below shows the correlations among the measures.

Table 3. Correlations

\begin{tabular}{|c|c|c|c|c|c|c|}
\hline & $\begin{array}{c}\text { Hope: } \\
\text { Pathways } \\
\text { Thinking }\end{array}$ & $\begin{array}{c}\text { Hope: } \\
\text { Agency } \\
\text { Thinking }\end{array}$ & $\begin{array}{c}\text { Self- } \\
\text { Compassion }\end{array}$ & $\begin{array}{c}\text { Relational } \\
\text { Social } \\
\text { Skill }\end{array}$ & $\begin{array}{c}\text { Communication } \\
\text { Apprehension }\end{array}$ & $\begin{array}{c}\text { Life } \\
\text { Satisfaction }\end{array}$ \\
\hline $\begin{array}{l}\text { Hope: } \\
\text { Pathways Thinking }\end{array}$ & 1 & $.45^{* *}$ & $.22^{* *}$ & $.37^{* *}$ & $.28^{* *}$ & $.19^{* *}$ \\
\hline $\begin{array}{l}\text { Hope: } \\
\text { Agency Thinking }\end{array}$ & $.45^{* *}$ & 1 & $.33^{* *}$ & $.38^{* *}$ & $.30^{* *}$ & $.55^{* *}$ \\
\hline $\begin{array}{l}\text { Self- } \\
\text { Compassion }\end{array}$ & $.22^{* *}$ & $.33^{* *}$ & 1 & $.41^{* *}$ & $.39^{* *}$ & $.32^{* *}$ \\
\hline $\begin{array}{l}\text { Relational } \\
\text { Social Skill }\end{array}$ & $.37^{* * *}$ & $.38^{* * *}$ & $.41^{* *}$ & 1 & $.60^{* * *}$ & $.32^{* *}$ \\
\hline $\begin{array}{l}\text { Communication } \\
\text { Apprehension }\end{array}$ & $.28^{* *}$ & $.30^{* *}$ & $.39^{* *}$ & $.60^{* *}$ & 1 & $.23^{* *}$ \\
\hline $\begin{array}{l}\text { Life } \\
\text { Satisfaction }\end{array}$ & $.19^{* * *}$ & $.55^{* *}$ & $.32^{* *}$ & $.32^{* *}$ & $.23^{* *}$ & 1 \\
\hline
\end{tabular}

Note: $\mathrm{n}=308 ;{ }^{* *} p<.01$

Pathways and agency thinking are moderately correlated, $r=.45$. Both components of hope are correlated with self-compassion (pathways $r=.22$, agency $r=.33$ ), relational social skill (pathways $r=.37$, agency $r=.38$ ), communication apprehension (pathways $r=.28$, agency $r=.30$ ), and life satisfaction (pathways $r=.19$, agency $r=.55$ ). Self-compassion is correlated with relational social skill ( $r=.41)$, communication apprehension $(r=.39)$, and life satisfaction $(r=.32)$. Relational social skill is correlated with communication apprehension $(r=.60)$ and with life satisfaction $(r=.32)$. Finally, communication apprehension is correlated with life satisfaction $(r=.23)$. 


\subsection{Path Analysis}

Figure 1 below shows the path analysis results.

Figure 1: Path analysis model showing the relationships of Hope to Self-Compassion, Relational Social Skill, Communication Apprehension, and Life Satisfaction.

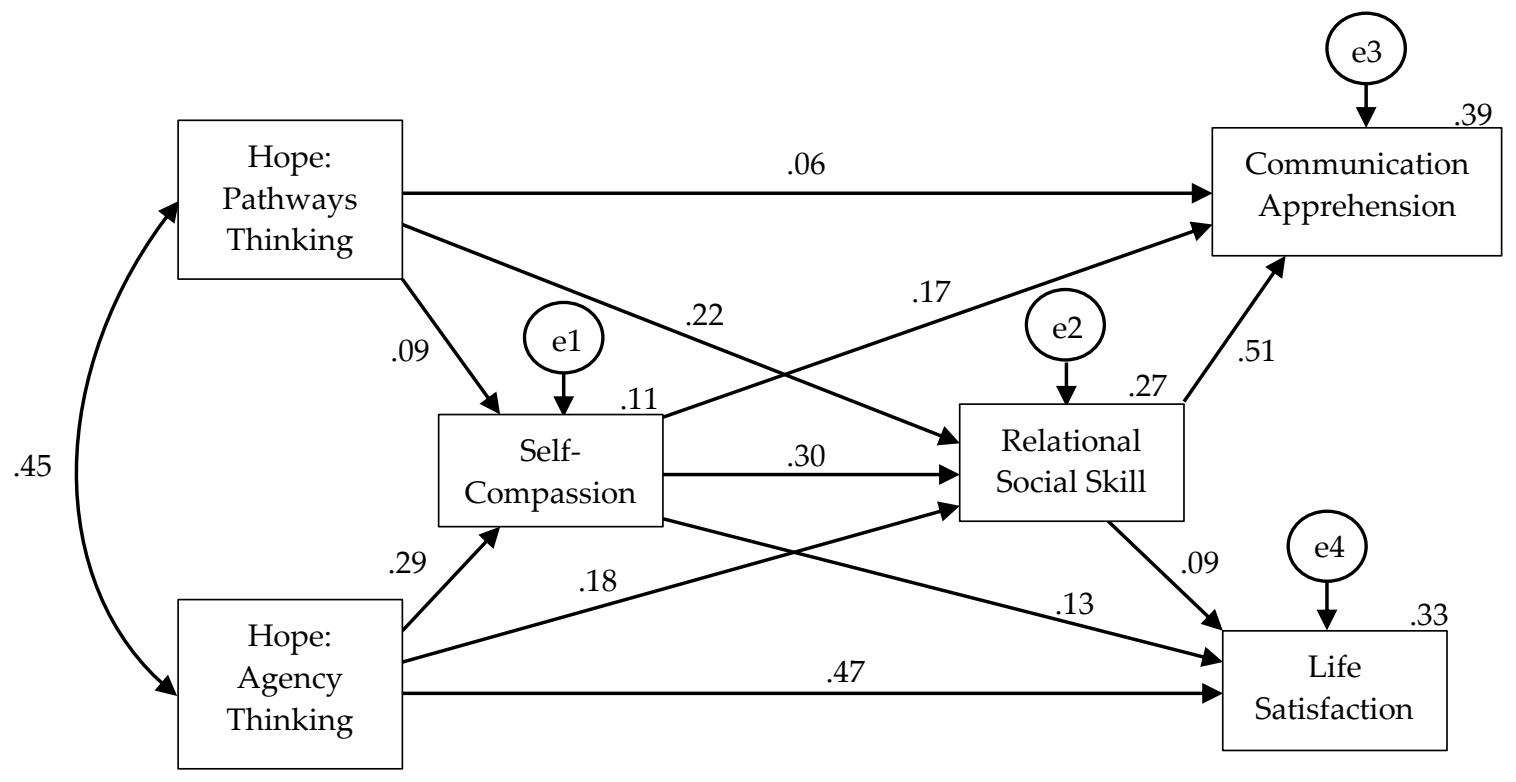

The model shows the moderate correlation between pathways and agency thinking $(\mathrm{r}=.45)$. More importantly, pathways $(\beta=.09)$ and agency $(\beta=.29)$ thinking both relate to self-compassion, accounting for $11 \%$ of the variance $(\mathrm{r} 2=.11)$. Pathways $(\beta=.22)$, agency $(\beta=.18)$, and selfcompassion $(\beta=.30)$ relate to relational social skill, and together account for $27 \%$ of the variance $(\mathrm{r} 2=.27)$. Pathways thinking $(\beta=.06)$, self-compassion $(\beta=.17)$, and relational social skill $(\beta=.51)$ account for $39 \%$ of the variance in communication apprehension $(\mathrm{r} 2=.39)$. Agency thinking $(\beta$ $=.47$ ), self-compassion $(\beta=.13)$, and relational social skill $(\beta=.09)$ account for $33 \%$ of the variance in life satisfaction $(\mathrm{r} 2=.33)$.

\section{Discussion}

The present results demonstrate the relationship of hope to psychological wellbeing (as represented in self-compassion), relational wellbeing (as indicated by relational social skill), communicative wellbeing (as suggested by reduced communication apprehension), and subjective wellbeing (as shown in life satisfaction). The path analysis model shows that hope, measured in pathways and agency thinking, has an influence on self-compassion, relational social skill, communication apprehension, and life satisfaction. The measures of pathways ( $r=$ .28) and agency $(r=.30)$ thinking produce moderate correlations with communication apprehension. These correlations, as shown in the model, are mediated by the influence of selfcompassion and relational social skill. The pathways thinking link to communication apprehension appears comparatively weak $(\beta=.06)$ in the model, and the agency thinking relationship $(\beta<.01)$ proves too weak to remain in the path analysis. Self-compassion shows a moderate correlation with communication apprehension $(r=.39)$ and is an influential link in the model $(\beta=.17)$. Relational social skill, with a relatively strong correlation to communication apprehension $(r=.60)$ also retains that relationship $(\beta=.51)$ in the model. These results suggest 
that the correlational relationship of pathways and agency thinking to communication apprehension is mediated by self-compassion and relational social skill.

Pathways thinking shows a weak correlation with life satisfaction $(r=.19)$ and too weak a relationship $(\beta<.01)$ for that link to remain in the path analysis model. Agency thinking shows a moderate correlation $(r=.55)$ and relationship to life satisfaction $(\beta=.47)$ in the model. Agency thinking maintains both a direct and a mediated relationship with life satisfaction. Pathways thinking produces neither. Self-compassion $(r=.32 ; \beta=.13)$ and relational social skill $(r=.32 ; \beta<$ .09) both show only moderate correlations and comparatively weak model relationships to life satisfaction.

The path analysis model shows other interesting sets of relationships. Pathways thinking is correlated to self-compassion $(r=.22)$, but produces only a weak relationship in the model ( $\beta$ $=.09)$. Agency thinking shows a moderate correlation to self-compassion $(r=.33)$ and maintains that relationship in the model $(\beta=.29)$. Pathways $(r=.37 ; \beta=.22)$ and agency thinking $(r=.38 ; \beta$ $=.18$ ) both demonstrate relationships to relational social skill. Overall, the path analysis model reveals a pattern of inter-acting influential relationships of pathways and agency thinking to selfcompassion, relational social skill, communication apprehension, and life satisfaction. This pattern of relationships shown in the model generally supports the hypotheses.

\subsection{Support for hypotheses}

Hypothesis one, that hope predicts self-compassion, is supported in terms of agency thinking. Agency thinking predicts less self-blaming, less self-criticism, and fewer unrealistic demands on oneself. A hopeful person who engages in agency thinking is more likely to be accepting of personal inadequacies and take a more mindful view of life. The more motivated a person is in pursuing hope, the more self-compassionate that person is as well.

Hypothesis two, that hope predicts more relational social skill, is supported by both pathways and agency findings. The model indicates that people who are less creative in their pathways thinking may also be lacking in the ability to relate to others socially. Those who are lacking in the motivation and self-efficacy of agency may find it more difficult to achieve relational success.

Hypothesis three, that hope predicts reduced communication apprehension, finds little direct support in the model, although the correlation table indicates moderate relationships. This suggests that pathways and agency thinking may affect communication apprehension. This effect, however, is mediated by self-compassion and relational social skill.

Hypothesis four, that hope predicts greater life satisfaction, finds both correlational and path analysis support for agency thinking. Having the agency to pursue one's goals translates into greater life satisfaction. This effect is stronger than the direct influence of either self-compassion or relational social skill.

Hypothesis five, that self-compassion mediates the relationship of pathways and agency thinking to relational social skill, communication apprehension, and life satisfaction finds support in the model. Self-compassion influences relational social skill, communication apprehension, and life satisfaction. People who are less compassionate toward themselves appear less relationally skilled, more apprehensive about communicating with others, and less satisfied with their lives.

Hypothesis six, that relational social skill mediates the relationship of pathways and agency thinking to communication apprehension and life satisfaction finds support in relation to communication apprehension and, to a lesser extent, life satisfaction. Goal-attainment is often achieved through relational-social interaction. Having relational social skill can facilitate the 
achievement of those goals with less communication apprehension. Along with agency thinking and self-compassion, relational social skill adds to life satisfaction.

\subsection{Conclusion}

One of the main goals of subjective wellbeing research is to identify the multiple influences and dynamic interplay of people's cognitive and affective states, socio-demographic contexts, experiences, expectations, and social comparisons (Galinha \& Pais-Ribeiro, 2011). The present path analysis model provides a look at the multiple simultaneous and interacting influences of habitual patterns in pathways and agency thinking that affect the experiences of self-compassion and relational social skill. These ways of thinking form inter-related influences on people's communication apprehension $\left(r^{2}=.39\right)$ and life satisfaction $\left(r^{2}=.33\right)$, accounting for a third of the variance in each.

Developing a fuller understanding of these habitual ways of thinking and their consequences is important because recent research studies show that intervention and instruction can increase both pathways and agency thinking (Feldman \& Dreher, 2012; Valle, Huebner, \& Suldo, 2006). Yohani (2008) obtained positive outcomes with an arts-based intervention program that helps refugee children engender more hopeful thinking about their life situations. Marques, Lopez, and Pais-Ribeiro (2011) report benefits in the use of an intervention program designed to foster hope in school-age children. Their results show an increase in life satisfaction as a result of goaldirected hopeful thinking. Feldman and Dreher (2012) demonstrate positive results with a hope intervention group gaining a better sense of life purpose and making more progress toward achieving life goals than either a control or relaxation group.

Past research shows the positive effects of hope on stress management, self-esteem, academic achievement, athletic performance, professional career enhancement, personal hygiene, and health practices (Valle, Huebner, \& Suldo, 2006). The present study reveals a pattern of influence that indicates that successful training in pathways and agency thinking may affect the experience of self-compassion, relational social skill, communication apprehension and life satisfaction. If the habits of hopeful thinking can be learned through intervention programs then changing these habits of thought may go beyond helping participants learn more hopeful ways of thinking to facilitating greater self-compassion, more skillful engagement in personal relationships, less communication apprehension, and an enhanced overall sense of life satisfaction. Hopeful thinking may not be the cause of these aspects of psychological, relational, social, and subjective wellbeing, but having hope can facilitate positive developments in each.

\section{Limitations and directions for future research}

As with all studies, there are limitations to this one. The present results are based on a single sample. Analysis of additional samples would increase the generalizability of the present findings. However, the present results do indicate that pathways and agency thinking are related to participants' perceptions of self-compassion, relational social skill, communication apprehension, and life satisfaction. Recognizing this pattern of influence is important, particularly in light of studies that show these habits of hopeful thinking can be learned.

Past research has looked at some of the psychological and behavioral consequences of hope. The present study increases our understanding of the relationship of hope to communication apprehension, compassion, social skill, and life satisfaction. Future research might compare the relational communication of hopeful thinkers to that of non-hopeful thinkers, examine their actual communication behaviors, analyze relational outcomes, or further connect the 
interpersonal communication and relational effects of hope to other psychological and behavioral outcomes.

The present results suggest that developing strategies of hopeful thinking can have practical consequences for people's psychological, relational, social, and subjective wellbeing. Hope, as represented in pathways and agency thinking, affects self-compassion, relational social skill, communication apprehension, and life satisfaction. These influential relationships should be explored further.

\section{Authors}

Laura R. Umphrey

Northern Arizona University

Laura.Umphrey@nau.edu

John C. Sherblom

University of Maine

\section{Publishing Timeline}

Received 14 July 2014

Accepted 26 September 2014

Published 31 December 2014

\section{References}

Akin, A., \& Eroglu, Y. (2013). Self-compassion and relational-interdependent self-construal. Studia Psychologica, 55(2), 111-121.

Alidina, K., \& Tettero, I. (2010). Exploring the therapeutic value of hope in palliative nursing. Palliative and Supportive Care, 8, 353-358. http://dx.doi.org/10.1017/S1478951510000155

Angner, E. (2011). The evolution of eupathics: The historical roots of subjective measures of wellbeing. International Journal of Wellbeing, 1(1), 4-41. http://dx.doi.org/10.5502/ijw.v1i1.14

Arroyo, A., \& Segrin, C. (2013). Family interactions and disordered eating attitudes: The mediating roles of social competence and psychological distress. Communication Monographs, 80(4), 399-424. http://dx.doi.org/10.1080/03637751.2013.828158

Ayres, J. (1988). Antecedents of communication apprehension: A reaffirmation. Communication Research Reports, 5, 76-83. http://dx.doi.org/10.1080/08824098809359804

Bailey, T. C., \& Snyder, C. R. (2007). Satisfaction with life and hope: A look at age and marital status. Psychological Record, 57(2), 233-240.

Bailey, T. C., Eng, W., Frisch, M. B., \& Snyder, C. R. (2007). Hope and optimism as related to life satisfaction. Journal of Positive Psychology, 2(3), 168-175. http://dx.doi.org/10.1080/17439760701409546

Baiocchi-Wagner, E. (2011). "Facing threats": Understanding communication apprehensive instructors' face loss and face restoration in the classroom. Communication Quarterly, 59(2), 221-238. http://dx.doi.org/10.1080/01463373.2011.563442

Baker, L. R., \& McNulty, J. K. (2011). Self-compassion and relationship maintenance: The moderating roles of conscientiousness and gender. Journal of Personality and Social Psychology, 100(5), 853-873. http://dx.doi.org/10.1037/a0021884

Bevan, J.L. (2009). Interpersonal communication apprehension, topic avoidance, and the experience of irritable bowel syndrome. Personal Relationships, 16(2), 147-165. http://dx.doi.org/10.1111/j.14756811.2009.01216.x

Bronk, K., Hill, P. L., Lapsley, D. K., Talib, T. L., \& Finch, H. (2009). Purpose, hope, and life satisfaction in three age groups. Journal of Positive Psychology, 4(6), 500-510.

http://dx.doi.org/10.1080/17439760903271439 
Burke, T. J., Woszidlo, A., \& Segrin C. (2012). Social skills, family conflict, and loneliness in families. Communication Reports, 25(2), 75-87. http://dx.doi.org/10.1080/08934215.2012.719461

Chang, E. C. (1998). Hope, problem-solving ability, and coping in a college, student population: Some implications for theory and practice. Journal of Clinical Psychology, 54, 953-962. http://dx.doi.org/10.1002/(SICI)1097-4679(199811)54:7<953::AID-JCLP9>3.0.CO;2-F

Chang, E. C., \& Banks, K. H. (2007). The color and texture of hope: Some preliminary findings and implications for hope theory and counseling among diverse racial/ethnic groups. Cultural Diversity and Ethnic Minority Psychology, 13(2), 94-103. http://dx.doi.org/10.1037/1099-9809.13.2.94

Davidson, C. L., Wingate, L. R., Rasmussen, K. A., \& Slish, M. L. (2009). Hope as a predictor of interpersonal suicide risk. Suicide \& Life-Threatening Behavior, 39(5), 499-507.

Demir, M. (2008). Sweetheart, you really make me happy: Romantic relationship quality and personality as predictors of happiness among emerging adults. Journal of Happiness Studies, 9, 257-277. http://dx.doi.org/10.1007/s10902-007-9051-8

Demir, M., Ozdemir, M., \& Weitekamp, L. A. (2007). Looking to happy tomorrows with friends: Best and close friendships as they predict happiness. Journal of Happiness Studies, 8, 243-271. http://dx.doi.org/10.1007/s10902-006-9025-2

Diener, E., Emmons, R., Larsen, J., \& Griffin, S. (1985). The satisfaction with life scale. Journal of Personality Assessment, 49(1), 71-75. http://dx.doi.org/10.1207/s15327752jpa4901 13

Dodge, R., Daly, A., Huyton, J., \& Sanders, L. (2012). The challenge of defining wellbeing. International Journal of Wellbeing, 2(3), 222-235. http://dx.doi.org/10.5502/ijw.v2i3.4

Feldman, D. B., \& Dreher, D. E. (2012). Can hope be changed in 90 minutes? Testing the efficacy of a single-session goal-pursuit intervention for college students. Journal of Happiness Studies, 13, 745-759. http://dx.doi.org/10.1007/s10902-011-9292-4

Fraas, M.R., \& Calvert, M. (2009). The use of narratives to identify characteristics leading to a productive life following acquired brain injury. American Journal of Speech-Language Pathology, 18(4), 315-328. http://dx.doi.org/10.1044/1058-0360(2009/08-0008)

Galinha, I., \& Pais-Ribeiro, J. L. (2011). Cognitive, affective and contextual predictors of subjective wellbeing. International Journal of Wellbeing, 2(1), 34-53. http://dx.doi.org/10.5502/ijw.v2i1.3

Gere, J., \& Schimmack, U. (2013). When romantic partners' goals conflict: Effects on relationship quality and subjective well-being. Journal of Happiness Studies, 14, 37-49. http://dx.doi.org/10.1007/s10902-0119314-2

Grewal, P. K., \& Porter, J. E. (2007). Hope Theory: A framework for understanding suicidal action. Death Studies, 31(2), 131-154. http://dx.doi.org/10.1080/07481180601100491

Gülay, H. (2011). Assessment of the prosocial behaviors of young children with regard to social development, social skills, parental acceptance-rejection and peer relationships. Journal of Instructional Psychology, 38(3/4), 164-172.

Helliwell, J. F., \& Wang, S. (2011). Trust and wellbeing. International Journal of Wellbeing, 1(1), $42-78$. http://dx.doi.org/10.5502/ijw.v1i1.3

Hellman, C. M., Pittman, M. K., \& Munoz, R. T. (2013). The first twenty years of the will and the ways: An examination of score reliability distribution on Snyder's dispositional hope scale. Journal of Happiness Studies, 14, 723-729. http://dx.doi.org/10.1007/s10902-012-9351-5

Honeycutt, J. M., Choi, C. W., \& DeBerry, J. R. (2009). Communication apprehension and imagined interactions. Communication Research Reports, 26(3), 228-236. http://dx.doi.org/10.1080/08824090903074423

Hoy, B. D., Suldo, S. M., \& Mendez, L. R. (2013). Links between parents' and children's levels of gratitude, life satisfaction, and hope. Journal of Happiness Studies, 14, 1343-1361. http://dx.doi.org/10.1007/s10902-012-9386-7

Ivtzan, I., Gardner, H. E., \& Smailova, Z., (2011). Mindfulness meditation and curiosity: The contributing factors to wellbeing and the process of closing the self-discrepancy gap. International Journal of Wellbeing, 1(3), 316-327. http://dx.doi.org/10.5502/ijw.v1i3.2

Jung, E. (2011). Identity gap: Mediator between communication input and outcome variables. Communication Quarterly, 59(3), 315-338. http://dx.doi.org/10.1080/01463373.2011.583501 
Kemer, G., \& Atik, G. (2012). Hope and social support in high school students from urban and rural areas of Ankara, Turkey. Journal of Happiness Studies, 13, 901-911. http://dx.doi.org/10.1007/s10902-011$\underline{9297-\mathrm{z}}$

La Placa, V., McNaught, A., \& Knight, A. (2013). Discourse on wellbeing in research and practice. International Journal of Wellbeing, 3(1), 116-125. http://dx.doi.org/10.5502/ijw.v3i1.7

Lopez, S. J., Snyder, C. R., \& Teramoto-Pedrotti, J. (2003). Hope: Many definitions, many measures. In S. J. Lopez \& C. R. Snyder (Eds.), Positive psychological assessment: A handbook of models and measures (pp. 91-107). Washington, DC: American Psychological Association.

Loveless, M., Powers, W. G., \& Jordan, W. (2008). Dating partner communication apprehension, selfdisclosure, and the first big fight. Human Communication, 11(2), 231-239.

Manusov, V. (2011). Being civil with ourselves. Spectra. (p. 16-19). Washington, D.C.: National Communication Association.

Marques, S. C., Lopez, S. J., \& Mitchell, J. (2013). The role of hope, spirituality and religious practice in adolescents' life satisfaction: Longitudinal findings. Journal of Happiness Studies, 14, 251-261. http://dx.doi.org/10.1007/s10902-012-9329-3

Marques, S. C., Lopez, S. J., \& Pais-Ribeiro, J. L. (2011). "Building hope for the future": A program to foster strengths in middle-school students. Journal of Happiness Studies, 12,139-152. http://dx.doi.org/10.1007/s10902-009-9180-3

Martin, M. W. (2008). Paradoxes of happiness. Journal of Happiness Studies, 9, 171-184. http://dx.doi.org/10.1007/s10902-007-9056-3

McCroskey, J. C. (1983). The communication apprehension perspective. Communication, 12, 1-25.

McCroskey, J. C., \& Beatty, M. J. (1984). Communication apprehension and accumulated communication state anxiety experiences: A research note. Communication Monographs, 51, 79-84. http://dx.doi.org/10.1080/03637758409390185

McCroskey, J. C., Beatty, M. J., Kearney, P., \& Plax, T. G. (1985). The content validity of the PRCA-24 as a measure of communication apprehension across communication contexts. Communication Quarterly, 33, 165-173. http://dx.doi.org/10.1080/01463378509369595

McCroskey, J. C., \& Sheahan, M. E. (1978). Communication apprehension social preference, and social behavior in a college environment. Communication Quarterly, 26(2), 41-45. http://dx.doi.org/10.1080/01463377809369292

Merz, M.Y. (2009). The effects of self-construal and perceived control on argumentativeness and communication apprehension. Journal of Intercultural Communication Research, 38(2), 59-75. http://dx.doi.org/10.1080/17475751003785084

Mongrain, M., Chin, J. M., \& Shapira, L. B. (2011). Practicing compassion increases happiness and selfesteem. Journal of Happiness Studies, 12, 963-981. http://dx.doi.org/10.1007/s10902-010-9239-1

Moraitou, D., \& Efklides, A. (2012). The wise thinking and acting questionnaire: The cognitive facet of wisdom and its relation with memory, affect, and hope. Journal of Happiness Studies, 13, 849-873. http://dx.doi.org/10.1007/s10902-011-9295-1

Neff, K. D. (2003a). Self-compassion: An alternative conceptualization of a healthy attitude toward oneself. Self \& Identity, 2, 85-101. http://dx.doi.org/10.1080/15298860309032

Neff, K.D. (2003b). The development and validation of a scale to measure self-compassion. Self $\mathcal{E}$ Identity, 2, 223-250. http://dx.doi.org/10.1080/15298860309027

Neff, K. D. (2011). Self-compassion, self-esteem, and well-being. Social and Personality Psychology, 5(1), 112. http://dx.doi.org/10.1111/j.1751-9004.2010.00330.x

Neff, K. D., \& Beretvas, S. N. (2013). The role of self-compassion in romantic relationships. Self and Identity, 12(1), 78-98. http://dx.doi.org/10.1080/15298868.2011.639548

Neff, K.D., Rude, S.S., \& Kirkpatrick, K.L. (2007). An examination of self-compassion in relation to positive psychological functioning and personality traits. Journal of Research in Personality 41, 908 916. http://dx.doi.org/10.1016/j.jp. 2006.08.002

Onwuegbuzie, A. J., \& Daley, C.E. (1999). Relation of hope to self-perception. Perceptual and Motor Skills, 88, 535-540. http://dx.doi.org/10.2466/pms.1999.88.2.535 
O'Sullivan, G. (2011). The relationship between hope, stress, self-efficacy, and life satisfaction among undergraduates. Social Indicators Research, 101(1), 155-172. http://dx.doi.org/10.1007/s11205-010-9662$\underline{z}$

Pearson, J. C., Child, J. T., DeGreeff, B. L., Semlak, J. L., \& Burnett, A. (2011). The influence of biological sex, self-esteem, and communication apprehension on unwillingness to communicate. Atlantic Journal of Communication, 19, 216-227. http://dx.doi.org/10.1080/15456870.2011.584509

Peterson, J. L. (2009). "You have to be positive." Social support processes of an online support group for men living with HIV. Communication Studies, 60(5), 526-541. http://dx.doi.org/10.1080/10510970903260368

Peterson, S. J., \& Byron, K. (2008). Exploring the role of hope in job performance: Results from four studies. Journal of Organizational Behavior, 29(6), 785-803. http://dx.doi.org/10.1002/job.492

Platsidou, M. (2013). Trait emotional intelligence predicts happiness, but how? An empirical study in adolescents and young adults. International Journal of Wellbeing, 3(2), 197-209.

Raes, F., Pommier, E., Neff, K. D., \& Van Gucht, D. (2011). Construction and factorial validation of a short form of the self-compassion scale. Clinical Psychology E Psychotherapy, 18, 250-255. http://dx.doi.org/10.1002/cpp.702

Reich, W. A., Kessel, E. M., \& Bernieri, F. J. (2013). Life satisfaction and the self: Structure, content, and function. Journal of Happiness Studies, 14, 293-308. http://dx.doi.org/10.1007/s10902-012-9332-8

Riggio, R.E. (1986). Assessment of basic social skills. Journal of Personality and Social Psychology. 51(3), 649660. http://dx.doi.org/10.1037/0022-3514.51.3.649

Riggio, R.E., \& Canary, D.R. (2003). Social skills inventory manual. Redwood City CA: Mind Garden.

Rosenberg, M.B. (2003). Nonviolent communication: A language of life. Encinitas, CA: Puddle Dancer Press.

Rubin, R. B., \& Rubin, A. M. (1989). Communication apprehension and satisfaction in interpersonal relationships. Communication Research Reports, 6(1), 13-20. http://dx.doi.org/10.1080/08824098909359827

Savage, J. S., \& Smith, A. B. (2007). General and specific goal orientations as correlates of adult student degree completion: Lessons from the community college of the air force. Journal of College Student Retention: Research, Theory and Practice, 9(4), 461-485. http://dx.doi.org/10.2190/CS.9.4.d

Segrin, C., Hanzal, A., Donnerstein, C., Taylor, M., \& Domschke, T. (2007). Social skills, psychological well-being, and the mediating role of perceived stress. Anxiety, Stress, and Coping, 20, 321-329. http://dx.doi.org/10.1080/10615800701282252

Shmotkin, D. (2005). Happiness in the face of adversity: Reformulating the dynamic and modular bases of subjective well-being. Review of General Psychology, 9, 291-325. http://dx.doi.org/10.1037/10892680.9.4.291

Snyder, C. R. (1994). The psychology of hope: You can get there from here. New York, NY: The Third Press.

Snyder, C. R. (2000). Handbook of hope: Theory, measures and applications. Academic Press: NY.

Snyder, C. R. (2002). Hope theory: Rainbows in the mind. Psychological Inquiry, 13(4), 249-275. http://dx.doi.org/10.1207/S15327965PLI1304 01

Snyder, C. R. (2005). Teaching: The lessons of hope. Journal of Social E Clinical Psychology, 24(1), $72-84$. http://dx.doi.org/10.1521/jscp.24.1.72.59169

Snyder, C.R., Ilardi, S.S., Cheavens, J., Michael, S.T., Yamhure, L. \& Sympson, S. (2000). The role of hope in cognitive-behavior therapies. Cognitive Therapy and Research, 24(6), 747-762. http://dx.doi.org/10.1023/A:1005547730153

Snyder, C. R., \& Lopez, S. J. (2007). Positive psychology: The scientific and practical explorations of human strengths. Thousand Oaks, CA, US: Sage Publications

Snyder, C. R., Harris, C., Anderson, J.R., Holleran, S.A., Irving, L.M., Sigmon, S.T., ... \& Harney, P. (1991). The will and the ways: Development and validation of an individual differences measure of hope. Journal of Personality and Social Psychology, 60, 570-585. http://dx.doi.org/10.1037/0022$\underline{3514.60 .4 .570}$

Spitzberg, B. H., \& Cupach, W. R. (1984). Interpersonal communication competence. Beverly Hills, CA: Sage.

Stajkovic, A.D. (2006). Development of a core confidence-higher order construct. Journal of Applied Psychology, 98, 1208-1224. http://dx.doi.org/10.1037/0021-9010.91.6.1208 
Suikkanen, J. (2011). An improved whole life satisfaction theory of happiness. International Journal of Wellbeing, 1(1), 149-166. http://dx.doi.org/10.5502/ijw.v1i1.6

Tabachnick, B. G., \& Fidell, L. S. (2013). Using multivariate statistics. Boston: Pearson.

Terry, M. L., \& Leary, M. R. (2011). Self-compassion, self-regulation, and health. Self E Identity, 10(3), 352362. http://dx.doi.org/10.1080/15298868.2011.558404

Uchida, Y., \& Ogihara, Y. (2012). Personal or interpersonal construal of happiness: A cultural psychological perspective. International Journal of Wellbeing, 2(4), 354-369. http://dx.doi.org/10.5502/ijw.v2.i4.5

Valle, M. F., Huebner, E. S., \& Suldo, S. M. (2006). An analysis of hope as a psychological strength. Journal of School Psychology, 44(5), 393-406. http://dx.doi.org/10.1016/j.jsp.2006.03.005

Wrench, J. S., Brogan, S. M., McCroskey, J. C., \& Jowi, D. (2008). Social communication apprehension: The intersection of communication apprehension and social phobia. Human Communication, 11(4), 409-429.

Yohani, S. C. (2008). Creating an ecology of hope: Arts-based interventions with refugee children. Child Adolescent Social Work Journal, 25, 309-323. http://dx.doi.org/10.1007/s10560-008-0129-x 